Steiger, R. H., Hansen, B. T., Schuler, Ch., Bär, M. T. \& Henriksen, N. in prep.: Isotopic age determinations revealing the polyorogenic nature of the southern Caledonian fold belt in East Greenland. Submitted to J. Geol.

Thyrsted, T. 1978: Structural and metamorphic studies in the East Greenland Caledonides between $72^{\circ}$ and $74^{\circ}$ N. Rapp. Grønlands Geol. Unders. 90, 94-99.

Wenk, E. \& Haller J. 1953: Geological explorations in the Petermann region, western part of Frænkels Land, East Greenland. Meddr Grønland 111, 3, 48 pp.

\title{
Observations on the Upper Permian of Wegener Halvø, East Greenland
}

\section{Lars Stemmerik}

The Upper Permian sediments of East Greenland are exposed from Scoresby Land in the south to Clavering $\varnothing$ in the north (fig. 30). The deposits on Wegener Halvø appear to be situated on the eastern side of the southern end of an elongated, approximately $80 \mathrm{~km}$ wide, sedimentary basin (Birkelund \& Perch-Nielsen, 1976). Whether this basin extended northwards to include the Upper Permian deposits of North Greenland, has yet to be established.

The Upper Permian sequence, which is predominantly marine limestones, shales and associated sandy units, rests unconformably on Devonian and Permo-Carboniferous rocks. All the sediments of Upper Permian age are referred to the Foldvik Creek Formation (Koch, 1929). This earlier work was revised, based on sections around Clavering $\emptyset$, and later the formation was divided into eight members (Maync, 1942, 1961). Recently, most of the units have been traced southwards into the Scoresby Land area (Perch-Nielsen et al., 1972). A regression in late Permian - early Triassic time affected the basin of deposition. Continuous sedimentation across the boundary is only known in the area of Schuchert Elv (Perch-Nielsen et al., 1972).

The present investigations are concerned with basin development and faunal distributions through this sequence (fig. 31). Fieldwork in summer 1978 aimed at establishing both faunal and sedimentological reference profiles. All work is supported by the Danish Natural Science Research Council (SNF).

\section{Observations and preliminary results}

In the southern part of Wegener Halvø sedimentation commenced with a 5-10 m (locally more than $30 \mathrm{~m}$ ) thick conglomerate, of probably marine origin. This Conglomerate Member of Myanc (1961) is overlain by a $20-40 \mathrm{~m}$ thick brecciated dolomite, which to the north marks the base of the Upper Permian. The breccia is mainly composed of blocks, of questionable Permian limestone, floating in a dolomitic matrix. General clast size of the breccia diminishes from $20 \mathrm{~cm}$ in the east of the basin to $3 \mathrm{~cm}$ in the west. In the south blocks exceed $10 \mathrm{~m}$ indicating a proximal source area.

The succeeding limestone thickness varies towards the central part of the basin, from 
Fig. 30. Distribution of Upper Permian sediments in East Greenland.

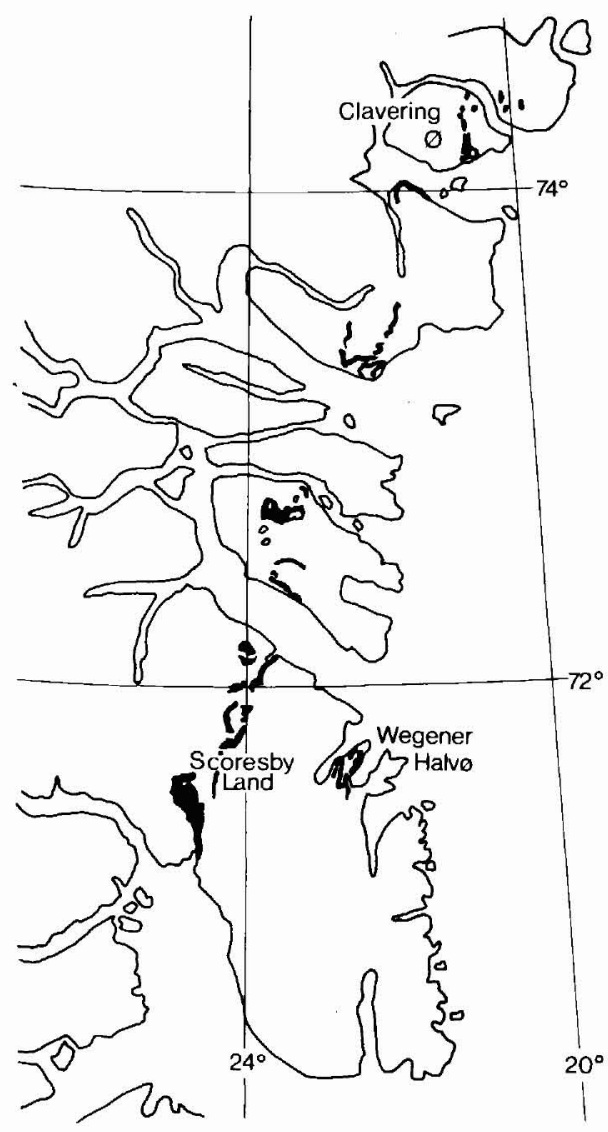

more than $150 \mathrm{~m}$ in the east of Wegener Halvø to less than $30 \mathrm{~m}$ in the west. This unit is mainly composed of structureless limestone alternating with laminated algal limestone and brecciated limestone. In combination, the dolomitic breccia and these limestones constitute the Limestone-Dolomite Member of Myanc (1961). In the uppermost part of the limestone, bioherms are frequently developed, composed of a massive core interfingering with interbedded limestones, and shaly marls with a rich fauna of productid brachiopods and fenestrate bryozoans. Isolated thin productid shell beds typically occur associated with the structureless limestone. These beds are referable to the Productus Limestone in the very restricted sense of Myanc (1942).

The Limestone-Dolomite Member is partly overlain by the black, bituminous Posidonia Shale probably deposited in small restricted basins between the topographically elevated limestone knolls.

In the northern part of Wegener Halvø, bedded limestone with marly layers constitutes the uppermost Permian and is referable to the Martinia Limestone of Myanc (1961). It was deposited on both the Posidonia Shale and on the Limestone. A single specimen of $\mathrm{Cy}$ - 


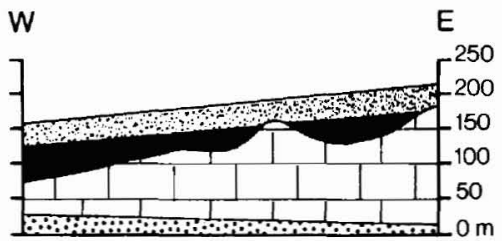

$12 \mathrm{~km}$

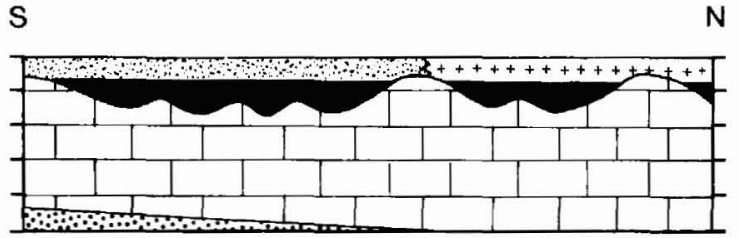

$20 \mathrm{~km}$

CONGLOMERATE MEMBER

\begin{tabular}{llll}
\hline LIMESTONE - DOLOMITE MEMBER & +++ & MARTINIA LIMESTONE \\
POSIDONIA SHALE & REDBED MEMBER
\end{tabular}

Fig. 31. Schematic sections showing the Upper Permian facies variation on Wegener Halvø.

clolobus sp. from the Martinia Limestone indicates an uppermost Permian age for at least part of this unit.

Towards the south the Martinia Limestone grades laterally into medium to coarse grained sandstones, locally rich in spiriferid brachiopods. These sandstones belong to the Redbed Member of Myanc (1961) and appear to be nearshore deposits, possibly indicating the beginning of the late Permian regression.

On Wegener Halvø the Upper Permian sequence is unconformably overlain by the Lower Triassic Wordie Creek Formation.

\section{References}

Birkelund, T. \& Perch-Nielsen, K. 1976: Late Palaeozoic-Mesozoic evolution of central East Greenland. In Escher, A. \& Watt, W. S. (edit.) Geology of Greenland, 305-339. Copenhagen: Geol. Surv. Greenland.

Koch, L. 1929: The geology of East Greenland. Meddr Grønland 73 (2), 1, 204 pp.

Maync, W. 1942: Stratigraphie und Faziesverhältnisse der oberpermischen Ablagerungen Ostgrönlands (olim "Oberkarbon-Unterperm") zwischen Wollaston Forland und dem Kejser Franz Josephs Fjord. Meddr Grønland 115, 2, 128 pp.

Maync, W. 1961: The Permian of Greenland. In Raasch, G. O. (edit.) Geology of the Arctic 1, 214-223. Toronto U.P.

Perch-Nielsen, K., Bromley, R., Birkenmajer, K. \& Aellen, M. 1972: Field observations in Palaeozoic and Mesozoic sediments of Scoresby Land and northern Jameson Land. Rapp. Grønlands geol. Unders. 48, 39-59.

Institut for Historisk Geologi og Palaentologi, University of Copenhagen,

$\emptyset$ ster Voldgade 10, $D K-1350$ Copenhagen $K$. 